\title{
Leaf growth dynamics in four plant species of the Patagonian Monte, Argentina
}

\author{
M. Victoria Campanella • Mónica B. Bertiller
}

Received: 16 August 2012/Accepted: 30 November 2012/Published online: 30 December 2012

(C) The Botanical Society of Japan and Springer Japan 2012

\begin{abstract}
Studying plant responses to environmental variables is an elemental key to understand the functioning of arid ecosystems. We selected four dominant species of the two main life forms. The species selected were two evergreen shrubs: Larrea divaricata and Chuquiraga avellanedae and two perennial grasses: Nassella tenuis and Pappostipa speciosa. We registered leaf/shoot growth, leaf production and environmental variables (precipitation, air temperature, and volumetric soil water content at two depths) during summer-autumn and winter-spring periods. Multiple regressions were used to test the predictive power of the environmental variables. During the summer-autumn period, the strongest predictors of leaf/shoot growth and leaf production were the soil water content of the upper layer and air temperature while during the winter-spring period, the strongest predictor was air temperature. In conclusion, we found that the leaf/shoot growth and leaf production were associated with current environmental conditions, specially to soil water content and air temperature.
\end{abstract}

Keywords Air temperature - Arid zones - Precipitation · Root system $\cdot$ Soil water content

M. V. Campanella $(\bowtie) \cdot$ M. B. Bertiller

Centro Nacional Patagónico (CENPAT, CONICET),

Boulevard Brown 2915, 9120 Puerto Madryn,

Chubut, Argentina

e-mail: campanella@cenpat.edu.ar

M. B. Bertiller

Universidad Nacional de la Patagonia San Juan Bosco,

Boulevard Brown 3700, 9120 Puerto Madryn, Chubut, Argentina

\section{Introduction}

Studying plant responses to climatic variables is an elemental key to understand the functioning of terrestrial ecosystems (Akpo 1997). An understanding of the responses of growth to precipitation and other climatic variables is critical for linking water pulse use to community dynamics (Snyder et al. 2004). In arid zones, precipitation is the major abiotic factor limiting plant growth (Noy Meir 1973). However, some authors highlighted that the duration of the growing period in some species was relatively independent of precipitation (Díaz and Granadillo 2005; Myers et al. 1998). Moreover, the availability of water in soil is more intimately related to foliage than precipitation (Ghazanfar 1997; Olivares and Squeo 1999; Peñuelas et al. 2004; Shackleton 1999). Nevertheless, other climatic variables such as air temperature and photoperiod have also been recognized as factors that could influence growth (Abd El-Ghani 1997; Pavón and Briones 2001). Furthermore, considering that global climate change leads to global warming and also may result in changes in precipitation distribution and pattern it is important to understand how foliage are related to climatic variables (Cheng et al. 2006; Easterling et al. 2000).

Plants vary widely in their phenological behavior according to morphological traits related to resource acquisition and conservation (Bertiller et al. 1991). In the Patagonian Monte, previous phenological studies highlighted that besides the peak of growth in spring there was another peak during late summer, depending on the year (Bisigato and López Laphitz 2009; Campanella 2009). Since leaf dynamics of species provides knowledge on the availability of forage resource, it is of main importance for livestock management knowing how leaf dynamics is related to environmental variables. We assessed leaf/shoot 
growth and leaf production in coexisting species during winter-spring and summer-autumn periods, and we also analyzed the environmental variables related to them.

\section{Methods}

Study site and species selected

The study was undertaken in La Esperanza Wildlife Refuge $\left(42^{\circ} 7^{\prime} 43.92^{\prime \prime} \mathrm{S} ; 64^{\circ} 57^{\prime} 40.99^{\prime \prime} \mathrm{W}\right)$, located in northeastern Chubut Province, Argentina. The average annual precipitation across the area is $200 \mathrm{~mm}$. Soils are a complex of Typic Petrocalcids-Typic Haplocalcids (Soil Survey Staff 1999) with a fractured calcium carbonate layer from 0.45 to $1 \mathrm{~m}$ below the soil surface (del Valle 1998). Soil texture types (USDA) are sandy or loamy sand (Rossi and Ares 2012) and volumetric soil moisture at field capacity is c.a. $25 \%$ (Bisigato and Bertiller 1999; Rostagno et al. 1991). The vegetation is a tall shrubland covering $40-60 \%$ of the soil surface, characteristic of the southern Monte (León et al. 1998) (Fig. 1).

We selected four dominant species of the two main life forms. The species selected were two evergreen shrubs: Larrea divaricata Cav. and Chuquiraga avellanedae L. and two perennial grasses: Nassella tenuis (Phil.) Barkworth and Pappostipa speciosa (Trin. \& Rupr.) Romasch.

\section{Climatic conditions}

We registered daily precipitation, maximum and minimum air temperature, and volumetric soil water content (10HS moisture capacitance/frequency domain sensor, Decagon Devices with an accuracy of $\pm 2 \%$ ) at two depths (5 and

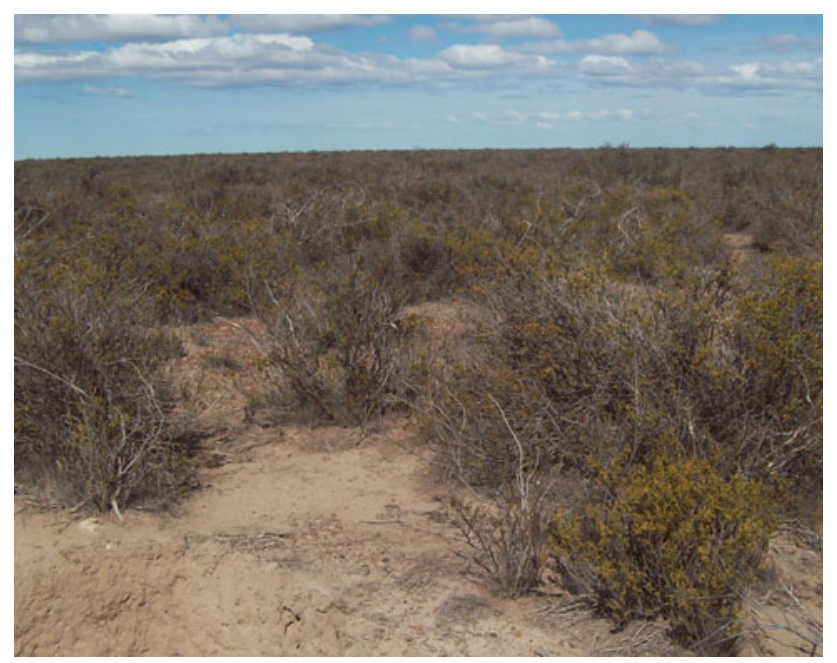

Fig. 1 The tall shrubland vegetation characteristic of the southern Monte
$30 \mathrm{~cm}$ ) with an automatic data recorder (21X Micrologger, Campbell Scientific) located at the study site.

Leaf/shoot growth and new leaf production

We randomly selected ten isolated plants of each focal species. Measurements were carried out during summerautumn (January 5-May 4, 2010) and winter-spring periods (June 29-December 14, 2010). We registered shoot growth and the number of new leaves in three randomly selected terminal branches per plant ( $\mathrm{n}=10$ plants per species) of $L$. divaricata and $C$. avellanedae. The terminal branches selected were tagged immediately below the apical bud. In the case of grasses ( N. tenuis and P. speciosa), we randomly selected three tillers per tussock $(\mathrm{n}=10$ tussocks per species) and registered leaf growth and the number of new leaves per tiller. Summer-autumn measurements were carried out at $3,7,10,14,21,52$ and 120 days after January 5, 2010 while winter-spring measurements were carried out at $8,16,30,51,65,90,129$ and 168 days after June 29, 2010.

Statistical analysis

We assessed the significance of differences in leaf/shoot growth and leaf production per shoot/tiller among species by ANOVA of repeated measures. In this analysis, we included species as fixed factor and dates as repeated measures within each plant or tussock. Linear correlation analyses between explanatory variables (climatic variables) were carried out. We used forward stepwise multiple regression analysis and principal component analyses to describe relationships between leaf/shoot growth, leaf production, and climatic variables. Climatic variables included cumulative rain, average volumetric soil water content at two depths and mean air temperature between sampling dates. All statistical analyses were performed with the SPSS package and the level of significance was $\alpha=0.05$ throughout the study.

\section{Results}

Precipitation and soil water content

Total precipitation was $154.98 \mathrm{~mm}$ during the study year (January-December 2010), the largest precipitation event occurred at the end of summer and smaller events occurred evenly distributed in the rest of the year. The soil water content was higher at $5 \mathrm{~cm}$ than at $30 \mathrm{~cm}$ depth for the two growth periods (Fig. 2). During the summer-autumn period, there was a negative correlation between soil water content at $5 \mathrm{~cm}$ depth and air temperature while during 

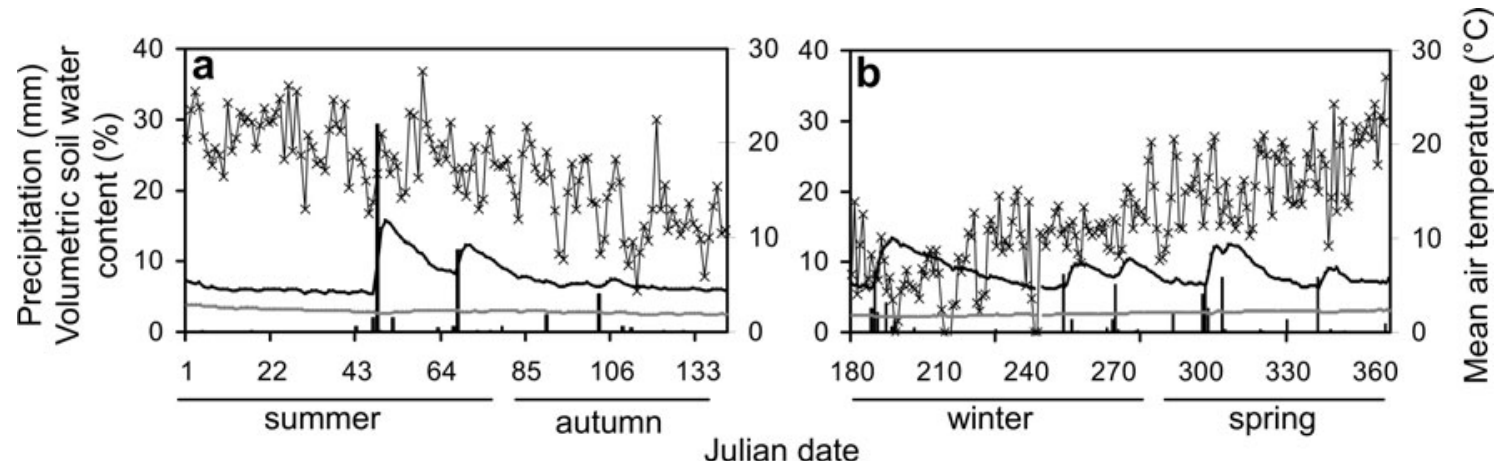

Fig. 2 Precipitation ( $\mathrm{mm}$ ) events (bars), daily volumetric soil water content (\%) at $5 \mathrm{~cm}$ (black line) and $30 \mathrm{~cm}$ (grey line) depth and daily mean air temperature (cross) during summer-autumn (a) and winter-spring periods (b)

Table 1 Spearman correlation matrix between climatic variables in the two periods of growth

\begin{tabular}{lcccc}
\hline & PP & SWC5 & SWC30 & TEMP \\
\hline Sumer-autumn period & & & & \\
PP & 1.000 & & & \\
SWC5 & $0.955^{* *}$ & 1.000 & & \\
SWC30 & $-0.839^{*}$ & $-0.800^{*}$ & 1.000 & \\
TEMP & -0.729 & $-0.855^{*}$ & 0.575 & 1.000 \\
Winter-spring period & & & & \\
PP & 1.000 & & & \\
SWC5 & -0.208 & 1.000 & & \\
SWC30 & 0.536 & -0.450 & 1.000 & \\
TEMP & 0.571 & -0.486 & $0.989^{* *}$ & 1.000 \\
\hline
\end{tabular}

For summer-autumn period $\mathrm{N}=7$ and for winter-spring period $\mathrm{N}=8(* P<0.05, * * P<0.01)$

$P P$ precipitation, $S W C 5$ volumetric soil water content at $5 \mathrm{~cm}$ depth, $S W C 30$ volumetric soil water content at $30 \mathrm{~cm}$ depth, TEMP mean air temperature

winter-spring period there was a positive correlation between soil water content at $30 \mathrm{~cm}$ depth and air temperature (Table 1). Taking into account that we found no evidence of soil water recharge at $30 \mathrm{~cm}$ depth (Fig. 2) and that the fluctuation in volumetric soil water content at $30 \mathrm{~cm}$ depth was lower than the sensor accuracy, we attribute the high correlation between temperature and SWC30 to the influence of temperature on capacitance/ frequency domain sensors. Because of that, SWC30 was excluded from the subsequent stepwise analysis.

Leaf/shoot growth and new leaf production

Chuquiraga avellanedae did not display new growth during the study period. We found significant differences in leaf/shoot growth in both growth period among species (summer-autumn: $F_{2,27}=50.51, \quad P<0.0001$; winterspring: $F_{2,27}=44.60, P<0.0001$ ), dates (summer-autumn:
$F_{1,27}=31.22, P<0.0001$; winter-spring: $F_{1,27}=46.56$, $P<0.0001)$ and we found a significant effect of species $\times$ date interaction (summer-autumn: $F_{2,27}=15.32$, $P<0.0001$; winter-spring: $\left.F_{2,27}=14.93, \quad P<0.0001\right)$ (Fig. 3a, b). Leaf/shoot growth and new leaf production in Larrea divaricata, $N$. tenuis and $P$. speciosa mostly occurred during spring and late summer-autumn. Leaf/shoot growth was higher in $P$. speciosa than in $N$. tenuis and L. divaricata, in both growth periods.

The number of new leaves per shoot/tiller also differed significantly among species (summer-autumn: $F_{2,27}=54.35, P<0.0001$; winter-spring: $F_{2,27}=68.61$, $P<0.0001$ ), dates (summer-autumn: $F_{1,27}=21.43$, $P<0.0001$; winter-spring: $\left.F_{1,27}=38.98, \quad P<0.0001\right)$ and we found a significant species $\times$ date interaction (summer-autumn: $F_{2,27}=6.32, P<0.0001$; winter-spring: $\left.F_{2,27}=20.56, \quad P<0.0001\right)$ in both growth periods (Fig. 3c, d). New leaf production was higher in $N$. tenuis during summer-autumn while during winter-spring was higher in L. divaricata. $N$. tenuis was the earliest and L. divaricata the latest in the onset of production of new leaves.

Relationships among growth measurements and climatic variables

During the summer-autumn growth period, soil water content in the upper layer $(5 \mathrm{~cm}$ depth) was the strongest predictor of the leaf/shoot growth and the number of new leaves per shoot/tiller (Table 2). Also, air temperature was found to be a strongest predictor of the both latter plant attributes. Air temperature was negatively associated with shoot growth in L. divaricata and the number of new leaves per tiller in P. speciosa (Fig. 4a). This was in relation to the negative interaction found between soil water content at $5 \mathrm{~cm}$ depth and air temperature, during summer-autumn period (Table 1). In contrast, during winter-spring period air temperature was the strongest predictor of the leaf/shoot 

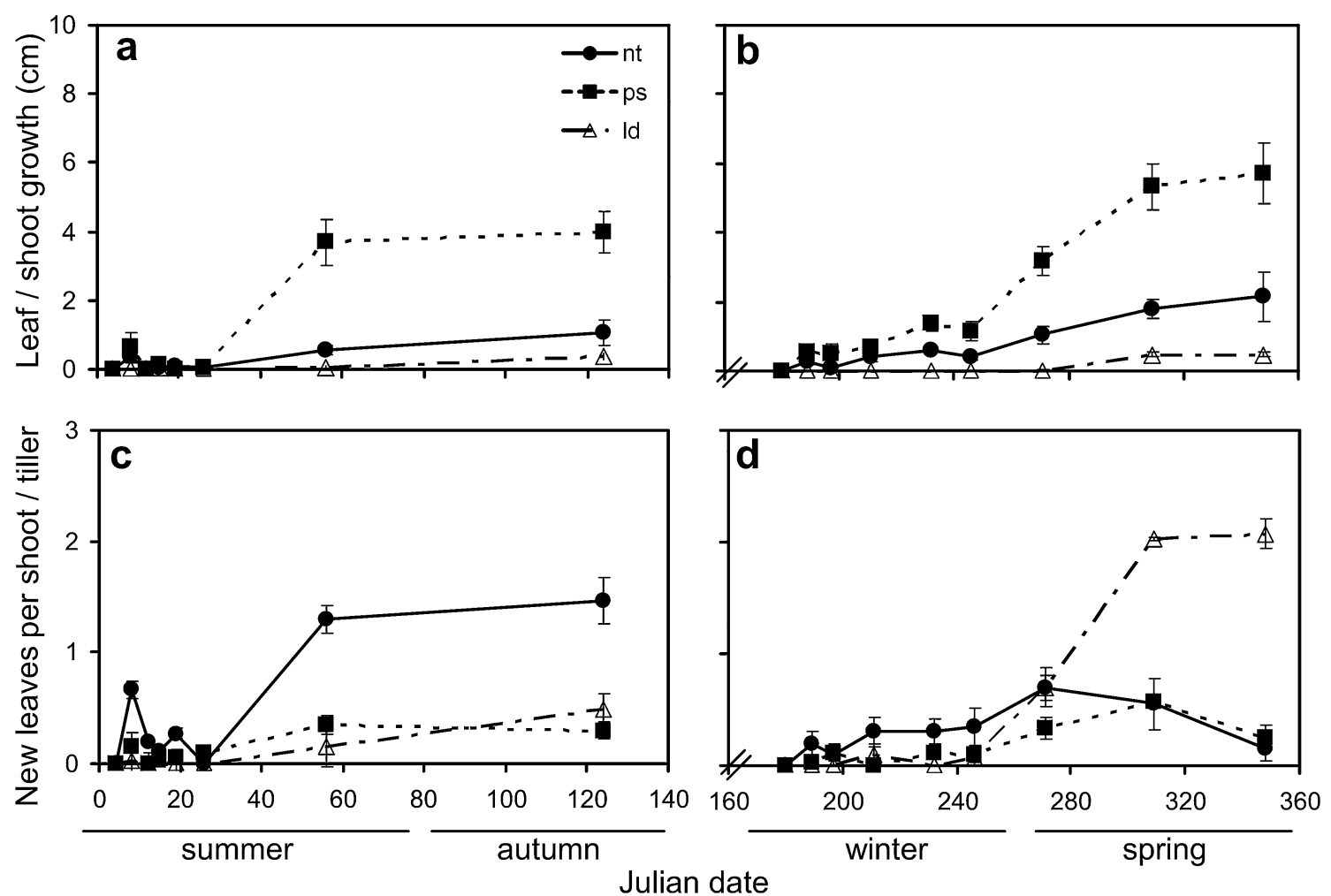

Fig. 3 Dynamics of leaf/shoot growth $(\mathbf{a}, \mathbf{b})$ and new leaf production (c, d) during summer-autumn and winter-spring of Nassella tenuis -nt- (filled circle and dark line), Pappostipa speciosa -ps- (filled square and dotted line) and Larrea divaricata -ld- (open triangle and

dashed line). Symbols are means and bars are standard errors. C. avellanedae did not show new growth during the studied periods (January 4-May 52010 and June 29-December 14 2010)

growth and the new leaves per shoot/tiller (Table 2). Air temperature was positively associated with leaf/shoot growth and new leaves per shoot/tiller (Fig. 4b).

\section{Discussion}

In water-limited environments, plant growth is constrained mostly to periods with high water availability (Ghazanfar 1997; Olivares and Squeo 1999; Peñuelas et al. 2004; Shackleton 1999). We found that leafing and growth processes in the studied plants were not directly controlled by precipitation but they were related to the current soil water content among other climatic variables. Jolly and Running (2004) emphasized that precipitation is a direct driver of the water balance in ecosystems, but it alone does not control the amount of water available for plants. Similarly, other studies showed a strong dependence of leaf extension and shoot elongation on the current water status in soil (Busso and Richards 1993; Haase et al. 1999; Otieno et al. 2005; Pugnaire et al. 1996) or close relationships between net photosynthesis and stomatal conductance and soil moisture in the upper soil layer (Montaña et al. 1995).

In three of the four species selected, growth was related to the water content in the upper soil layer $(5 \mathrm{~cm}$ depth) in summer-autumn, independently from growth forms. In the same way, species belonging to different functional types in a cold desert ecosystem also used the same water sources (Schwinning et al. 2005a, b). Accordingly, these results would suggest that almost all desert plants are "drinking from the same cup" (Hunter 1989; Reynolds et al. 2004) and that grasses and shrubs could be potential competitors for water soil resources (Montaña et al. 1995). However, some differences in the onset of leaf emergence and leaf/ shoot growth among the studied species could indicate the existence of species-specific thresholds related to functional and structural constraints (Ogle et al. 2004) and provide evidence for temporal functional asynchrony among coexisting species (Chesson et al. 2004).

The differences between the two evergreen shrubs, L. divaricata and $C$. avellanedae, could be associated with differences in the rooting depth and the spatial pattern of water content during the study period. Throughout the study period the water content in the upper soil was higher than at $30 \mathrm{~cm}$ depth. The total precipitation during the studied year was $154.98 \mathrm{~mm}$, less than the long-term average $(200 \mathrm{~mm})$ and was characterized by pulses smaller than $11 \mathrm{~mm}$ with only a single relatively large event of $30 \mathrm{~mm}$ at the end of summer. Previous studies in the Patagonian Monte reported refilling of deep soil layers 
Table 2 Relationships between leaf/shoot growth and new leaves per shoot/tiller, and climatic variables for the three species in the two growth periods

\begin{tabular}{lllc}
\hline & $\begin{array}{l}\text { Strongest } \\
\text { predictors }\end{array}$ & $r^{2}$ & $P$ \\
\hline $\begin{array}{l}\text { Summer-autumn period } \\
\text { (a) Leaf/shoot growth }\end{array}$ & & & \\
$\quad$ Larrea divaricata & -TEMP & 0.65 & 0.03 \\
$\quad$ Pappostipa speciosa & SWC5 & 0.99 & $<0.0001$ \\
Nassella tenuis & SWC5, PP & 0.99 & $<0.0001$ \\
(b) New leaves per shoot/tiller & & & \\
$\quad$ Larrea divaricata & SWC5 & 0.95 & $<0.0001$ \\
Pappostipa speciosa & -TEMP & 0.75 & 0.01 \\
$\quad$ Nassella tenuis & SWC5 & 0.92 & 0.001 \\
Winter-spring period & & & \\
(a) Leaf/shoot growth & & & \\
$\quad$ Larrea divaricata & TEMP & 0.76 & 0.007 \\
Pappostipa speciosa & TEMP & 0.85 & 0.001 \\
$\quad$ Nassella tenuis & TEMP & 0.85 & 0.001 \\
(b) New leaves per shoot/tiller & & & \\
$\quad$ Larrea divaricata & TEMP, SWC5 & 0.95 & 0.001 \\
$\quad$ Pappostipa speciosa & PP & 0.68 & 0.01 \\
Nassella tenuis & ns & $\mathrm{ns}$ & $\mathrm{ns}$ \\
\hline
\end{tabular}

Acronyms of climatic variables like in Table 1 . A negative sign in the strongest predictor column indicates a negative relationship. For summer-autumn period $\mathrm{N}=7$ and for winter-spring period $\mathrm{N}=8$ $n s$ indicates no significant model

after large precipitation events during winter and showed strong differences in water content among years (Bisigato and López Laphitz 2009; Coronato and Bertiller 1997). Moreover, Wierenga et al. (1987) and Reynolds et al. (1999) reported no soil recharge at $30 \mathrm{~cm}$ and below in some dry years in the Chihuahuan Desert. This could have benefited leaf/shoot growth of $L$. divaricata with a dimorphic root system (Rodríguez et al. 2007). Instead C. avellanedae with deep roots (Bertiller et al. 1991) using water preferentially below $30 \mathrm{~cm}$ depth could have experienced water limitation for leaf/shoot growth in comparison with the other species. In arid environments, precipitation events of approximately 10-20 mm could considerably enhance soil water content only in the upper soil profile (Bisigato and López Laphitz 2009; Coronato and Bertiller 1997; Reynolds et al. 2004).

These findings are consistent with the experimental evidence suggesting that an increment in the number of large precipitation events would favor shrub growth while small precipitation events would tend to promote grass development (Bates et al. 2006; Fay et al. 2002; Gao and Reynolds 2003; Knapp et al. 2002; Sala et al. 1982). Despite that $C$. avellanedae did not produce new growth during the period of study, this species has xerophitic leaf attributes
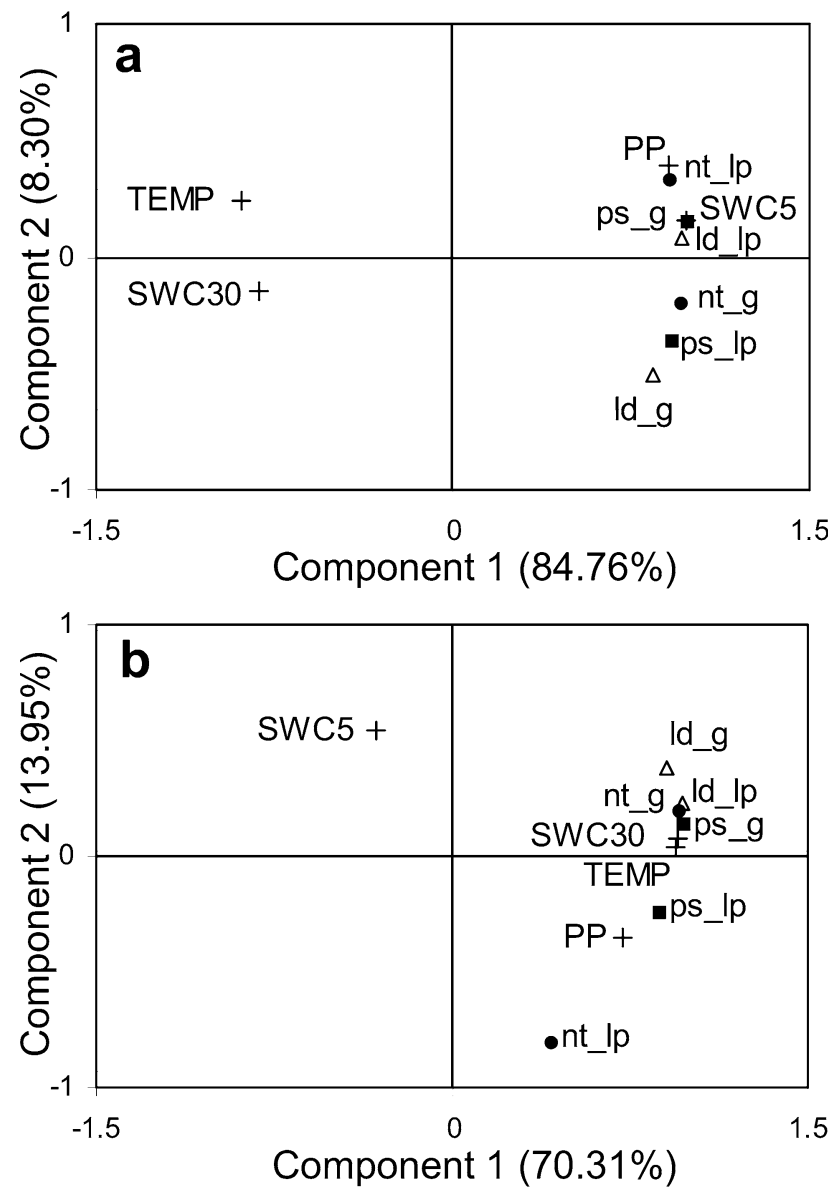

Fig. 4 Principal component analyses showing relationships among leaf/shoot growth (_g) and new leaf production (_lp) of Nassella tenuis -nt- (filled circle), Pappostipa speciosa -ps- (filled square) and Larrea divaricata -ld- (open triangle) and environmental variables for (a) summer-autumn and (b) winter-spring periods. Environmental variables acronyms like in Table 1 . Symbols represent mean values

(Campanella and Bertiller 2011) that contribute to overcome extending hot and dry periods (Wright et al. 2004). Because temporal and spatial variation in water availability could modify competitive interactions among plants in desert ecosystems (Briones et al. 1998) it is important to perform long term research. Thus, additional studies will be required to get a better understanding of growth pattern of the species studied with above average precipitation and/or with high number of large precipitation events.

We found that air temperature was also related to leaf/ shoot growth and leaf production. In accordance, a study that simulated phenological characteristics of two dominant grass species in a semi-arid steppe ecosystem highlighted the importance of develop a water-heat-based phenological model (Yuan et al. 2007). Air temperature affects plant growth due to changes in photosynthetic rate, $\mathrm{CO}_{2}$ losses by respiration, and enhanced photorespiration (Prieto et al. 2009). This is in agreement with other works showing a high sensitivity of leaf extension and growth of 
semi-arid grasses to temperature fluctuations (Busso and Richards 1993; Pugnaire et al. 1996). Additionally, other study showed that the differences in leaf dynamics between 2 years were more related to differences in air temperature and air humidity than to precipitation inputs (Schwinning et al. 2005a). As well, other works revealed that the initiation of spring growth was more related to soil temperature than to precipitation or soil moisture (Chew and Chew 1965; Reynolds et al. 1999). Similarly, Peñuelas et al. (2007) showed that, at the stand level, temperature and soil moisture of the preceding months determined the annual biomass production. Thus, Schwinning et al. (2005b) highlighted that primary productivity in deserts is not a direct response to precipitation.

In conclusion, we found that the leaf/shoot growth and leaf production were affected by current environmental conditions. Leaf/shoot growth and leaf production were not a direct response to precipitation, but were strongly related to soil water content and air temperature. Our research suggests that any change in water availability and temperature due to global warming could have consequences on species-specific plant responses in leaf/shoot growth and leaf production. This study also highlighted the importance of soil water dynamics of the different layers as well as root depth in controlling leaf dynamics of arid plants. However, since our study lacks of soil water content replication these issues should be validated in future studies.

Acknowledgments We thank to "Fundación Patagonia Natural" for the permission to access to the Wildlife Refuge "La Esperanza". This research was funded by BID 1728 OC-AR-PICT 04 08-20454, National Agency for Scientific and Technological Promotion. Authors are grateful to Dr. Atsushi Kume and two anonymous reviewers for their useful comments.

\section{References}

Abd El-Ghani M (1997) Phenology of ten common plant species in western Saudi Arabia. J Arid Environ 35:673-683

Akpo LE (1997) Phenological interactions between tree and understory herbaceous vegetation of a sahelian semi-arid savanna. Plant Ecol 131:241-248

Bates JD, Svejcar T, Miller RF, Angell RA (2006) The effects of precipitation timing on sagebrush steppe vegetation. J Arid Environ 64:670-697

Bertiller MB, Beeskow AM, Coronato F (1991) Seasonal environmental variation and plant phenology in arid Patagonia (Argentina). J Arid Environ 21:1-11

Bisigato AJ, Bertiller MB (1999) Seedling emergence and survival in contrasting soil microsites in Patagonian Monte shrubland. J Veg Sci 10:335-342

Bisigato AJ, López Laphitz RM (2009) Ecohydrological effects of grazing-induced degradation in the Patagonian Monte, Argentina. Austral Ecol 34:545-557

Briones O, Montaña C, Ezcurra E (1998) Competition intensity as a function of resource availability in a semiarid ecosystem. Oecologia 116:365-372
Busso CA, Richards JH (1993) Leaf extension rate in two tussock grasses. Effects of eater stress and clipping. Acta Oecol 14:3-15

Campanella MV (2009) Ecología de la senescencia foliar en plantas de ecosistemas áridos. PhD Thesis, Universidad Nacional del Comahue, Centro Regional Universitario Bariloche, Argentina, p 136

Campanella MV, Bertiller MB (2011) Is N-resorption efficiency related to secondary compounds and leaf longevity in coexisting plant species of the arid Patagonian Monte, Argentina? Austral Ecol 36:395-402

Cheng X, An S, Li B, Chen J, Lin G, Liu Y, Lou Y, Liu S (2006) Summer rain pulse size and rainwater uptake by three dominant desert plants in a desertified grassland ecosystem in northwestern China. Plant Ecol 184:1-12

Chesson P, Gebauer R, Schwinning R, Huntly N, Wiegand K, Ernest M, Sher A, Novoplansky A, Weltzin J (2004) Resources pulses, species interactions, and diversity maintenance in arid and semiarid ecosystems. Oecologia 141:236-253

Chew RM, Chew AE (1965) The primary productivity of a desertshrub (Larrea tridentata) community. Ecol Monogr 35:355-375

Coronato FR, Bertiller MB (1997) Climatic controls of soil moisture dynamics in an arid steppe of Northern Patagonia, Argentina. Arid Soil Res Rehab 11:277-288

del Valle HF (1998) Patagonian soils: a regional síntesis. Ecología Austral 8:103-123

Díaz M, Granadillo E (2005) The significance of episodic rains for reproductive phenology and productivity of trees in semiarid regions of northwestern Venezuela. Trees 19:36-348

Easterling DR, Meehl GA, Parmesan C, Changnon SA, Karl TR, Mearns LO (2000) Climate extremes: observations, modeling, and impacts. Science 289:2068-2074

Fay PA, Carlisle JD, Danner BT, Lett MS, McCarron JK, Stewart C, Knapp AK, Blair JM, Collins Sl (2002) Altered rainfall patterns, gas exchange and growth in grasses and forbs. Int J Plant Sci 163:549-557

Gao Q, Reynolds JF (2003) Historical shrub-grass transitions in the northern Chihuahuan Desert: modeling the effects of shifting rainfall seasonality and event size over a landscape gradient. Glob Change Biol 9:1475-1493

Ghazanfar SA (1997) The phenology of desert plants: a 3 year study in a gravel desert wadi in northern Oman. J Arid Environ 35:407-417

Haase P, Pugnaire FI, Clark SC, Incoll LD (1999) Environmental control of canopy dynamics and photosynthetic rate in the evergreen tussock grass Stipa tenacissima. Plant Ecol 145:327-339

Hunter RB (1989) Competition between adult and seedling shrubs of Ambrosia dumosa in the Mojave Desert Great Basin. Nature 49:79-84

Jolly WM, Running SW (2004) Effects of precipitation and soil water potential on drought deciduous phenology in the Kalahari. Glob Change Biol 10:303-308

Knapp AK, Fay PA, Blair JM, Collins SL, Smith MD, Charlisle JD, Harper CW, Danner BT, Lett MS, McCarron JK (2002) Rainfall variability, carbon cycling, and plant species diversity in a mesic grassland. Science 298:2202-2205

León RJC, Bran D, Collantes M, Paruelo JM, Soriano A (1998) Grandes unidades de la vegetación de la Patagonia extra andina. Ecología Austral 8:125-144

Montaña C, Cavagnaro B, Briones O (1995) Soil water use by coexisting shrubs and grasses in the Southern Chihuahuan desert, Mexico. J Arid Environ 31:1-13

Myers BA, Williams RJ, Fordyce I, Duff GA, Emaus D (1998) Does irrigation affect leaf phenology in deciduous and evergreen trees of the savannas of northern Australia? Aust J Ecol 23:329-339

Noy Meir I (1973) Desert ecosystems: environment and producers. Annu Rev Ecol Syst 4:25-51 
Ogle K, Wolpert RL, Reynolds JF (2004) Reconstructing plant root area and water uptake profiles. Ecology 85:1967-1978

Olivares SO, Squeo FA (1999) Patrones fenológicos en especies arbustivas del desierto costero del norte-centro de Chile. Rev Chil Hist Nat 72:353-370

Otieno DC, Schmidt MWT, Kinyamario JI, Tenhunen J (2005) Responses of Acacia tortilis and Acacia xanthophloea to seasonal changes in soil water availability in the savanna region of Kenya. J Arid Environ 62:377-400

Pavón NP, Briones O (2001) Phenological patterns of nine perennial plants in an intertropical semi-arid Mexican scrub. J Arid Environ 49:265-277

Peñuelas J, Filella I, Zhang X, Llorens L, Ogaya R, Lloret F, Comas P, Estiarte M, Terradas J (2004) Complex spatiotemporal phenological shifts as a response to rainfall changes. New Phytol 161:837-846

Peñuelas J, Prieto P, Beier C et al (2007) Response of plant species richness and primary productivity in shrublands along a northsouth gradient in Europe to seven years of experimental warming and drought. Reduction in primary productivity in the heat and drought year of 2003. Glob Change Biol 13:25632581

Prieto P, Peñuelas J, Llusia J, Asensio D, Estiarte M (2009) Effects of experimental warming and drought on biomass accumulation in a Mediterranean shrubland. Plant Ecol 205:179-191

Pugnaire FI, Haase P, Incoll LD, Clark C (1996) Response of the tussock grass Stipa tenacisima to catering in a semi-arid environment. Func Ecol 10:265-274

Reynolds JF, Virginia RA, Kemp PR, de Soyza AG, Tremmel DC (1999) Impact of drought on desert shrubs: effects of seasonality and degree of resource island development. Ecol Monogr 69:69-106

Reynolds JF, Kemp PR, Ogle K, Fernández RJ (2004) Modifying the pulse-reservë paradigm for deserts of North America: precipitation pulses, soil water, and plant responses. Oecologia 141: 194-210

Rodríguez MV, Bertiller MB, Bisigato AJ (2007) Are fine roots of both shrubs and perennial grasses able to occupy the upper soil layer? A case study in the arid Patagonian Monte with nonseasonal precipitation. Plant Soil 300:281-288
Rossi MJ, Ares JO (2012) Depression storage and infiltration effects on overland flow depth-velocity-friction at desert conditions: field plot results and model. Hydrol Earth Syst Sci 16:3293-3307

Rostagno CM, del Valle HF, Videla L (1991) The influence of shrubs on some chemical and physical properties of an aridic soil in north-eastern Patagonia, Argentina. J Arid Environ 20:179-188

Sala OE, Laurenroth WK, Parton WJ (1982) Plant recovery following prolonged drought in a shortgrass steppe. Agric Meteor 27:49-58

Schwinning S, Starr BI, Ehleringer JR (2005a) Summer and winter drought in a cold desert ecosystem (Colorado Plateau) part I: effects on soil water and plant water uptake. J Arid Environ 60:547-566

Schwinning S, Starr BI, Ehleringer JR (2005b) Summer and winter drought in a cold desert ecosystem (Colorado Plateau) part II: effects on plant carbon assimilation and growth. J Arid Environ 61:61-78

Shackleton CM (1999) Rainfall and topo-edaphic influences on woody community phenology in South African savannas. Global Ecol Biogeogr 8:125-136

Snyder KA, Donovan LA, James JJ, Tiller RL, Richards JH (2004) Extensive summer water pulses do not necessarily lead to canopy growth of Great Basin and northern Desert shrubs. Oecologia 141:325-334

Soil Survey Staff (1999) Soil taxonomy: a basic system of soil classification for making and interpreting soil surveys. Agricultural Handbook 436, USDA Soil Conservation Service. US Government Printing Office, Washington, DC

Wierenga PJ, Hendricx JHM, Nash NM, Ludwing J, Daugherty LA (1987) Variation of soil and vegetation with distance along a transect in the Chihuahuan desert. J Arid Environ 13:53-63

Wright IJ, Reich PB, Westoby M, Ackerly DD, Baruch Z, Bongers F, Cavender-Bares J, Chapin T, Cornelissen JHC, Diemer M, Flexas J, Garnier E, Groom PK, Gulias J, Hikosaka K, Lamont BB, Lee T, Lee W, Lusk C, Midgley JJ, Navas ML, Niinemets Ü, Oleksyn J, Osada N, Poorter H, Poot P, Prior L, Pyankov VL, Roumet C, Thomas SC, Tjoelker MG, Veneklaas EJ, Villar R (2004) The worldwide leaf economics spectrum. Nature 428:821-827

Yuan W, Zhou G, Wang Y, Han X, Wang Y (2007) Simulating phenological characteristics of two dominant grass species in a semi-arid steppe ecosystem. Ecol Res 22:784-791 